\title{
GIL-based heat and temperature module: Empowering scientific inquiry literacy of junior high school students
}

\author{
Dian Kurvayanti Innatesari*1, Sajidan ${ }^{1}$, Sukarmin $^{2}$, Ririn Setyaningdyah Hanggawati ${ }^{3}$ \\ ${ }^{1}$ Science Education of Post Graduate Program, Sebelas Maret University, Surakarta, Indonesia \\ ${ }^{2}$ Physics Education of Post Graduate Program, Sebelas Maret University, Surakarta, Indonesia \\ ${ }^{3}$ Teacher, SMPN 3 Pare, Kediri, Indonesia \\ *Corresponding Address: diankurvayanti@student.uns.ac.id
}

\begin{tabular}{|c|c|}
\hline Article Info & ABSTRACT \\
\hline Article history: & \multirow{4}{*}{$\begin{array}{l}\text { This research aims to determine the effectiveness of the heat and } \\
\text { temperature module based on the Guided-Inquiry Laboratory (GIL) model. } \\
\text { The type of this research was a quasi-experimental research with a pretest- } \\
\text { posttest control group design. The samples were the seventh grade of one of } \\
\text { junior high school in Kediri, as many as } 60 \text { students, with two classes: } \\
\text { module as experiment class and existing class as control class. The module } \\
\text { class was treated using a GIL-based module and existing class using } \\
\text { modules commonly used at school. The sampling technique used in this } \\
\text { research was purposive sampling. The instrument used to collect data on } \\
\text { scientific inquiry literacy was a multiple-choice test. This study found that } \\
\text { there are statistically significant differences between the module and the } \\
\text { existing class with an Effect Size (ES) of } 0,413 \text {. The average score of } \\
\text { scientific inquiry literacy N-Gains score calculation in the module class was } \\
\text { higher by } 0,68 \text { compared to the existing class Of } 0,47 \text {. The result indicates } \\
\text { that there is a medium impact of applying heat and temperature module to } \\
\text { the indicator of scientific inquiry literacy. These findings contribute that } \\
\text { employing the GIL-based heat and temperature module proved to be } \\
\text { effective in the quality of science learning among module class students. }\end{array}$} \\
\hline $\begin{array}{l}\text { Received: July } 28^{\text {th }}, 2019 \\
\text { Accepted: March } 09^{\text {th }}, 2020 \\
\text { Published: October } 29^{\text {th }}, 2020\end{array}$ & \\
\hline Keywords: & \\
\hline $\begin{array}{l}\text { Module; } \\
\text { Scientific inquiry literacy. }\end{array}$ & \\
\hline
\end{tabular}

(C) 2020 Physics Education Department, UIN Raden Intan Lampung, Indonesia.

\section{INTRODUCTION}

A competitive generation is needed in the development of science and technology that refers to scientific literacy skills (Setiawan et al., 2017). Science literacy is needed by students to face the global world and bring them into a competitive generation (Innatesari et al., 2019). Science education policy documents worldwide highlight the importance of scientific literacy (Murphy et al., 2019).

The cultivation of scientific literacy in recent science education can be improved by experiencing and understanding scientific inquiry by which scientific knowledge is formed (Jeon \& Choi, 2016). Scientific inquiry is one of the components of scientific literacy (Kusnadi et al., 2017; NGSS, 2013; Odegaard et al., 2015). Scientific inquiry is not only the development of process skills, which also includes observation, inference, classification, speculation, measure, questioning, interpretation, and data analysis (Wang et al., 2015). It can be concluded that scientific inquiry is part of scientific literacy. A research result indicated that the students' scientific inquiry literacy (SIL) in Kediri was relatively low (Innatesari et al., 2019). Teaching material is required to facilitate the students in developing their SIL ability (Iskandar et al., 2019). 
The selection of high-quality textbooks is very important to maximize effective scientific literacy in the science classroom (Mcdonald, 2015). There should be a textbook of science that contains science literacy (Ardianto \& Pursitasari, 2017). The preliminary study showed that analysis of science teaching materials based on scientific literacy indicators used by one of the junior high schools in the Kediri Regency showed that the indicators of identifying and controlling variables and constructing and interpreting graphs had not been seen in teaching materials used by the schools. These findings indicated that several indicators are not yet complete. So that it is felt less helpful to students in science literacy. Besides, the existing module is only a brief explanation directly, so it does not help students in finding their knowledge (Astuti et al., 2019). The GILbased module can improve existing modules by adding components that are not yet available.

Learning outcomes can be the benchmark of the learning quality. The mastery of heat and temperature material in the National Examination (UN) in one of the junior high schools in the Kediri Regency of the last three years in the 2015/2016 school year amounted to $52.80 \%$ and the 2016/2017 school year amounted to $51.29 \%$. The data shows a decreased percentage and still below this standard KKM. Then, there should be improvements in the learning process in the classroom (Prihmardoyo et al., 2017). A questionnaire has been conducted that showed $78 \%$ of students experienced difficulties in understanding the heat and temperature material. This low achievement becomes the reason to increase the mastery of heat and temperature material.

Inquiry-based learning can be used to empower scientific literacy (Lederman et al., 2014; Ristanto et al., 2017). One of inquiry-based learning is Guided-Inquiry Laboratory. Students who use the inquiry laboratory have a significant $\mathrm{N}$ gain in scientific literacy skills (Aulia et al., 2018; Kusnadi et al., 2017). Inquiry learning refers to both an instructional approach and curriculum materials for the students to learn science and scientific ways of obtaining knowledge (Ronnebeck, 2016).

Learning activities in the module make it easier for students to improve understanding of the concepts learned (Gunawan et al., 2019; Mulhayatiah et al., 2019). The characteristics of the GIL-based temperature and heat module consist of five syntaxes, which is are to orienting students towards a phenomenon, identifying problems that arise from phenomena, formulating problems from identification, forming hypotheses (observations), organizing students to design and conduct experiments (manipulation), Making observations on the results of the experiment (generalization), communicating the results of observations to other groups (verification), and resolving the questions (applications) contained in each learning activity (Wenning, 2011). The use of the module in learning can provide benefits to students as independent teaching material, evaluation, and student learning resources (Dhamija et al., 2014; Fitriyani \& Indriaturrahmi, 2015; Serrat et al., 2014).

Some studies have been conducted using the Guided-Inquiry laboratory to improve scientific literacy. While this study refers to the scientific inquiry literacy indicators contained in ScInqLiT. The ScInqLiT instrument has been used by (Kusnadi et al., 2017) to measure the scientific inquiry particular in microbiology lab activities of prospective biology teachers in the Institute of Teacher's Education (LPTK). Material about temperature and heat is also related to things in daily life such as how the. It would be interesting if the mechanism of regulating the temperature of the human body was integrated into science learning especially in terms of temperature and heat and presented in the form of inquiry. Also, scientific literacy researched by (Arifin \& Sunarti, 2017; Diana, 2016; Setiawan et al., 2017; Sujudi et al., 2020;) uses PISA indicators. 
Therefore, it becomes a novelty thing that is different from previous research to use a GIL-based module in learning to empower scientific inquiry literacy. The purpose of this research was to develop GIL-based heat and temperature module to empower scientific inquiry literacy in the Kediri Regency junior high schools.

\section{METHODS}

This research was conducted using the descriptive quantitive method. The subjects of this research were the students of the seventh grade of one of the junior high schools in Kediri Regency which covered both existing and module classes. The samples consisted of 60 students with two classes. Both classes took pretest first before treatment then at the end of the lesson the posttest was given. The module was developed using Research and Development method referred to Borg and Gall's model.

The time of the research is the second semester of the academic year 2018/2019. The sample selection technique used was purposive sampling. The effectiveness employed a quasi-experiment method with a pretest-posttest control group design. The design of the chosen research method can be seen in Table 1.

Table 1. Research design

\begin{tabular}{lccc}
\hline Class & Pretest & Treatment & Posttest \\
\hline Module & $\mathrm{O}_{1}$ & $\mathrm{X}$ & $\mathrm{O}_{1}{ }^{\prime}$, \\
Existing & $\mathrm{O}_{2}$ & - & $\mathrm{O}_{2}{ }^{2}$ \\
\hline
\end{tabular}

\section{Procedure}

Module feasibility is important for the development module, so the heat and temperature modules based on the GuidedInquiry laboratory need to be validated in advance by experts or validators, consisting of 2 material experts, 1 media expert, 1 linguist, and 1 expert in learning instruments. The feasibility of this module showed that the module was feasible with the average values of $84.19 \%$ and $92.18 \%$ of the very good category. In limited field trials, the assessment scores of GIL-based heat and temperature module from 2 education practitioners and 15 students are respectively 81.25 with very good categories and 81.67 with a very good category. The module is feasible to empower scientific literacy because of the strategic value of the module base. Each syntax of the GIL learning model can train indicators of scientific inquiry literacy. The characteristic of Guided-Inquiry laboratory-based module accommodated learning syntax including observation, manipulation, generalization, verification, and application integrated into scientific inquiry literacy, as presented in Table 2.

The instrument used were 45 items on topic heat and temperature material. This research was scientific inquiry literacy test refers to ScInqLiT using the indicator that entailed indicator identifying and controlling variables; recognizing and analyzing alternative explanations; communicating the result; drawing appropriate conclusions from evidence; understanding and analyzing data; constructing and interpreting graphs; constructing hypotheses; designing experimental procedures, and identifying problems to be investigated. Meanwhile, the reliability test obtained Cronbach Alpha 0,663 , meaning that each of the items is a highly reliable category. 
Table 2. The storyboard of GIL-based module

\section{GIL Syntax}

\section{Learning Activity}

Observation

Manipulation

Generalization Presented observation tables and graph diagrams can train students to write the results of experiments both in tables and graphs. Furthermore, this will train students in analyzing data and drawing conclusions based on experimental data obtained. influence an event and determine the relationships between variables in hypotheses sentences on their own.

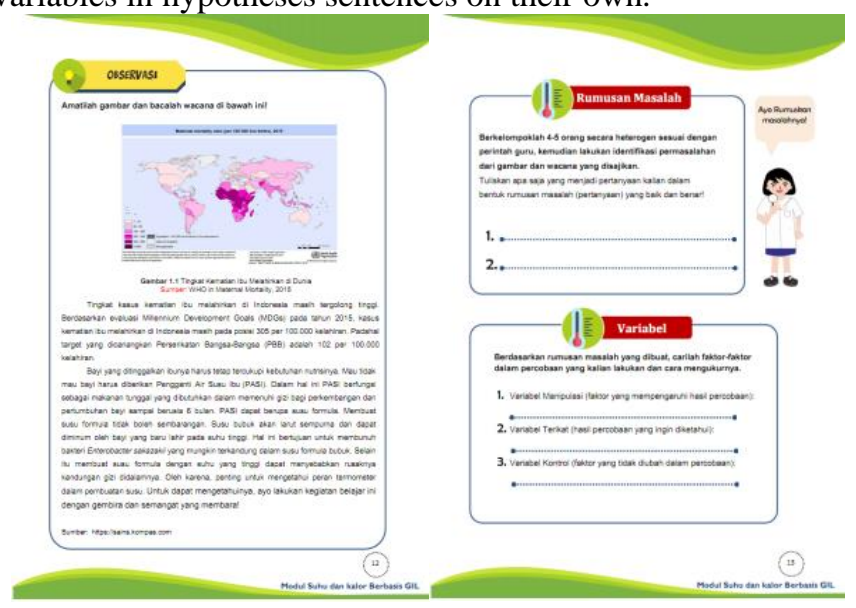

After the students write their hypotheses, the students design experiments independently and conducting experiments including compiling the title and purpose of the experiment, selecting tools and experimental material, and compiling the steps of the experiment.

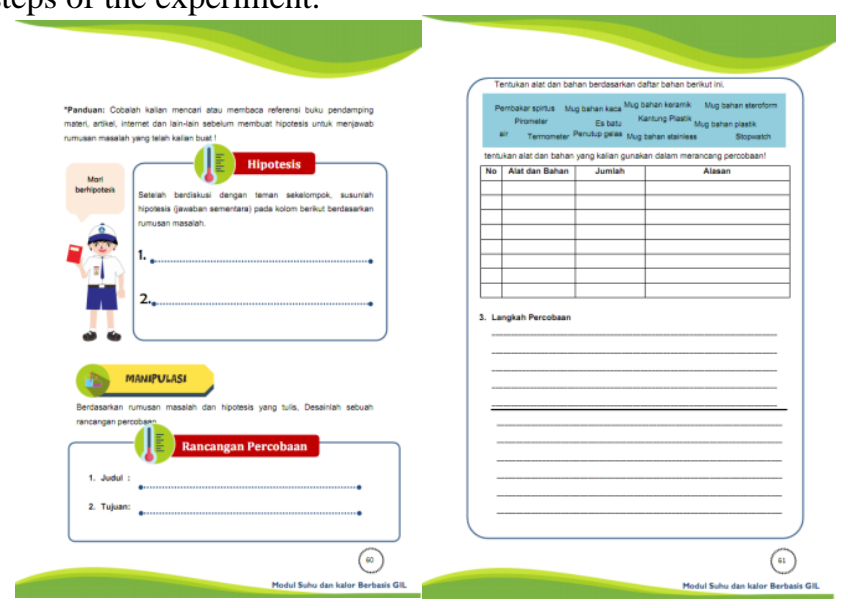

\section{The Potential for Scientific Inquiry Literacy}

Identifying and controlling variables, Constructing hypotheses, Identifying problems to be investigated

Drawing appropriate conclusions from evidence, understanding and analyzing data, constructing and interpreting graphs 


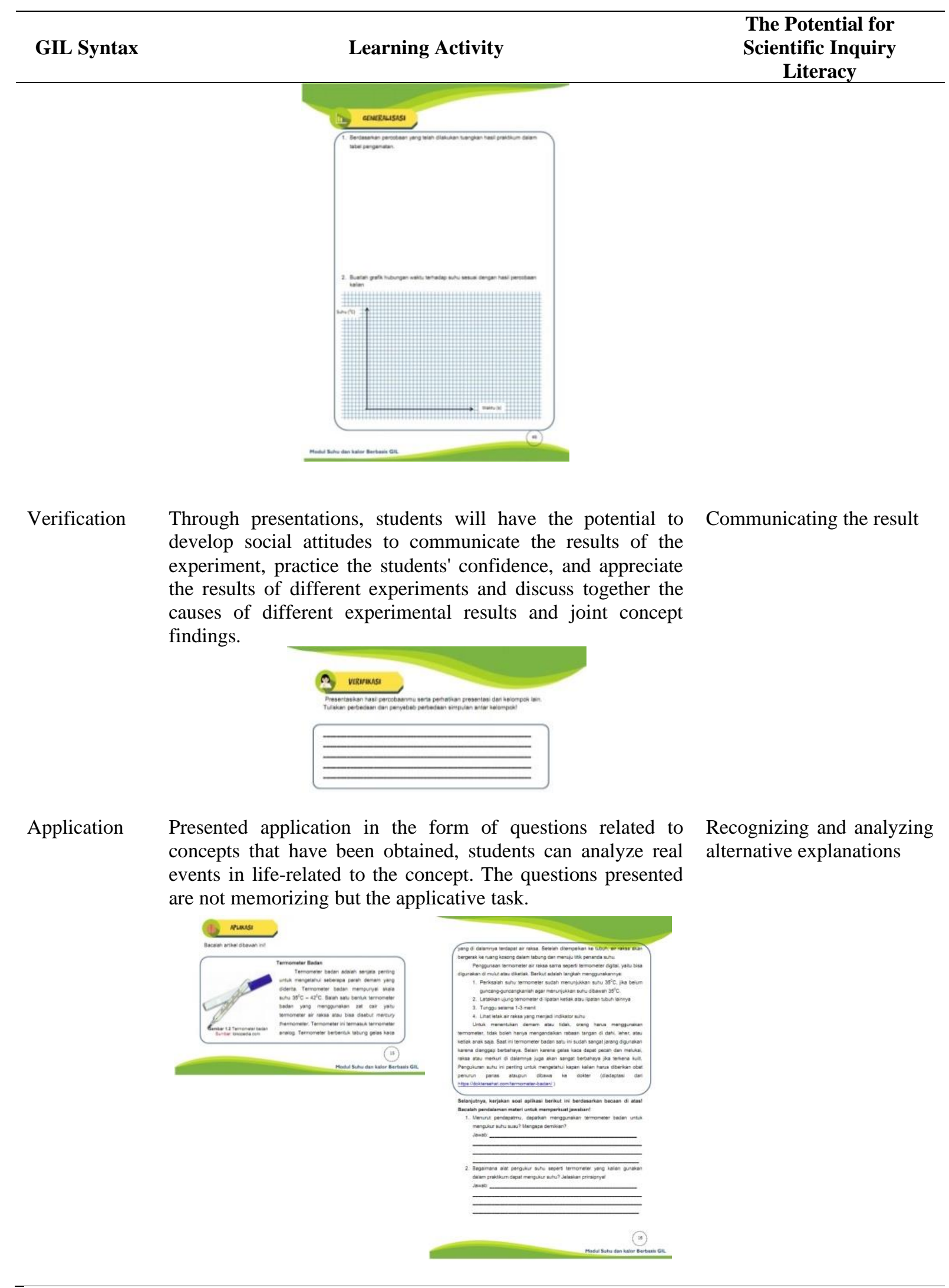




\section{Data Analysis Technique}

To find out the effectiveness of the module after the learning, the data obtained from the scientific inquiry literacy test would be applied normality test with Kolmogorov-Smirnov Test and box's M test as homogeneity test. The hypothesis testing was conducted using a multivariate of variance (MANOVA) at a significance level $<0.05$. While the Effect Size test was done with the interpretation as presented in Tabel 3. Effect size can be analyzed using partial eta-squared.

Table 3. Criteria for effect size

\begin{tabular}{cc}
\hline Effect Size & Remark \\
\hline $0-0,2$ & Very low \\
$0,21-0,50$ & low \\
$0,51-1,00$ & Medium \\
$>1,00$ & High \\
\hline & Source: (Cohen, 1988)
\end{tabular}

The analysis of the N-Gain score for the improvement of scientific inquiry literacy per aspect to find out the effectiveness of the GIL-based heat and temperature module in empowering every aspect. The calculation of the N-Gain score can be categorized using an interpretation table conforming to Table 4.
Table 4. Category for N-gain

\begin{tabular}{cc}
\hline $\mathbf{N}-G a i n(g)$ & Category \\
\hline $0,7<\mathrm{g}<1$ & High \\
$0,3 \leq \mathrm{g} \leq 0,7$ & Medium \\
$0<\mathrm{g}<0,3$ & Low \\
\hline
\end{tabular}

\section{RESULT AND DISCUSSION}

The data on students' scientific inquiry literacy (SIL) were obtained by giving 45 multiple-choice test items in which refers to 9 aspects of scientific inquiry literacy. The example of scientific inquiry literacy is presented in Table 5. Furthermore, field implementation tests in the class of module and existing class presented in Table 6 . Based on Table 6 shows the result of the descriptive analysis of scientific inquiry literacy before treatment was given and after treatment was given to the module and existing classes. The result showed that between the module and existing class, the average of the pre-test is almost the same at 44,14 and 44,51. It can indicate that the classes used in this research have the same capabilities. Meanwhile, the average posttest showed that the module class is 82,00 .

Table 5. The example of SIL instrument

\begin{tabular}{lrl}
\hline Indicator of Question & \multicolumn{1}{c}{ Indicator of SIL } & \multicolumn{1}{c}{ Question } \\
\hline $\begin{array}{l}\text { Given illustrations } \\
\text { of the expansion }\end{array}$ & $\begin{array}{l}\text { Recognizing and } \\
\text { analyzing alternative } \\
\text { event, students } \\
\text { explanations }\end{array}$ & $\begin{array}{l}\text { Ajeng cooks water and fills the water almost full. At a certain } \\
\text { temperature, it appears that some water spills from the neck of } \\
\text { the teapot before the water boils. From that event, Siska said } \\
\text { that the expansion of the volume of liquid was greater than the } \\
\text { examples that }\end{array}$ \\
$\begin{array}{l}\text { support the } \\
\text { argument about }\end{array}$ & $\begin{array}{l}\text { expansion of the volume of solid matter. Other events which } \\
\text { correspond are ... } \\
\text { expansion }\end{array}$ & $\begin{array}{l}\text { a. evaporation of seawater is caused by solar heating } \\
\text { b. a glass full of water, the outer wall of the glass will get wet } \\
\text { c. the glass that initially filled with full water will freeze with } \\
\text { a bulging top surface } \\
\text { d. a glass full of ice will completely melt and no spilled water. }\end{array}$ \\
\hline
\end{tabular}

Table 6. Descriptive statistic of SIL in module and existing

\begin{tabular}{|c|c|c|c|c|c|}
\hline Data & Class & Average & Max & Min & SD \\
\hline \multirow[t]{2}{*}{ Pre-test } & Module & 44,14 & 66,67 & 28,89 & 10,29 \\
\hline & Existing & 44,51 & 66,67 & 33,33 & 7,94 \\
\hline \multirow[t]{2}{*}{ Post-test } & Module & 82,00 & 93,33 & 71,11 & 5,93 \\
\hline & Existing & 70,89 & 91,10 & 55,56 & 9,32 \\
\hline \multirow[t]{2}{*}{ N-Gain } & Module & 0,68 & 0,83 & 0,29 & 0,12 \\
\hline & Existing & 0,47 & 0,82 & 0,22 & 0,13 \\
\hline
\end{tabular}


The multivariate of variance (MANOVA) was conducted to determine whether there is a difference between the pre-test and post-test both in the module and the existing class. The assumption test in the form of normality using KolmogorovSmirnov and homogeneity tests using Box's $M$ conducted before MANOVA. The summary of the result of the prerequisite MANOVA test presented in Table 7. Therefore, furthermore using MANOVA test results can be seen in Table 8 .
Based on Table 8 showed that the data value of pre-test and post-test of scientific inquiry literacy in the module and existing class are normally distributed and homogeneous. The result of the multivariate of MANOVA analysis obtained sig. of 0,000 . The significance value is less than 0,05 (sig. $<0,05$ ), so that $\mathrm{Ho}$ is rejected. Thus, heat and temperature module based on GIL applied to module class is effective in empowering students' scientific inquiry literacy because there are different results between both classes.

Table 7. The assumption test of MANOVA students' scientific inquiry literacy

\begin{tabular}{ccccc}
\hline Class & Class & Sig. & $\alpha$ & Result \\
\hline Normality & Module & 0,200 & 0,05 & Normal \\
& Existing & 0,200 & 0,05 & Normal \\
Homogeneity & & 0,624 & 0,05 & $\begin{array}{c}\text { Homogen } \\
\text { ous }\end{array}$ \\
\hline
\end{tabular}

Table 8. The result of the MANOVA test

\begin{tabular}{|c|c|c|c|c|}
\hline Data & Sig. & $\alpha$ & Result & Decision \\
\hline Multivariate & $0,000 *)$ & 0,05 & Sig. $<\alpha$ & $\mathrm{H}_{\mathrm{o}}$ is rejected \\
\hline \multicolumn{5}{|l|}{ Univariate } \\
\hline Identifying and controlling variables & $0,000 *)$ & 0,05 & Sig. $<\alpha$ & $\mathrm{H}_{\mathrm{o}}$ is rejected \\
\hline $\begin{array}{l}\text { Recognizing and analyzing alternative } \\
\text { explanations }\end{array}$ & 0,197 & 0,05 & Sig. $>\alpha$ & $\mathrm{H}_{\mathrm{o}}$ is accepted \\
\hline Communicating the result & 0,536 & 0,05 & Sig. $>\alpha$ & $\mathrm{H}_{\mathrm{o}}$ is accepted \\
\hline $\begin{array}{l}\text { Drawing appropriate conclusions from the } \\
\text { evidence }\end{array}$ & $\left.0,056^{*}\right)$ & 0,05 & Sig. $<\alpha$ & $\mathrm{H}_{\mathrm{o}}$ is rejected \\
\hline Understanding and analyzing data & 0,061 & 0,05 & Sig. $>\alpha$ & $\mathrm{H}_{\mathrm{o}}$ is accepted \\
\hline Constructing and interpreting graphs & $0,000 *)$ & 0,05 & Sig. $<\alpha$ & $\mathrm{H}_{\mathrm{o}}$ is rejected \\
\hline Constructing hypotheses & 0,330 & 0,05 & Sig. $>\alpha$ & $\mathrm{H}_{\mathrm{o}}$ is accepted \\
\hline Designing experimental procedures & $0,019 *)$ & 0,05 & Sig. $<\alpha$ & $\mathrm{H}_{\mathrm{o}}$ is rejected \\
\hline Identifying problems to be investigated & $0,000 *)$ & 0,05 & Sig. $<\alpha$ & $\mathrm{H}_{\mathrm{o}}$ is rejected \\
\hline
\end{tabular}

Table 9. The result of N-Gain on each indicator of SIL in module class

\begin{tabular}{lcc}
\hline \multicolumn{1}{c}{ Indicator } & N-Gain & Criteria \\
\hline Identifying and controlling variables & 0,64 & Medium \\
Recognizing and analyzing alternative explanations & 0,64 & Medium \\
Communicating the result & 0,57 & Medium \\
Drawing appropriate conclusions from the evidence & 0,77 & High \\
Understanding and analyzing data & 0,74 & High \\
Constructing and interpreting graphs & 0,64 & Medium \\
Constructing hypotheses & 0,65 & Medium \\
Designing experimental procedures & 0,77 & High \\
Identifying problems to be investigated & 0,79 & High \\
\hline
\end{tabular}

The result of univariate in the significance value is more than 0,05 (sig. $>0,05$ ), so that $\mathrm{H}_{0}$ is rejected. Thus, it can be concluded that there is a significant 
difference between the module and the existing class on the indicator identifying and controlling variables; drawing appropriate conclusions from evidence; constructing and interpreting graphs; designing experimental procedures; identifying problems to be investigated.

$\mathrm{N}$-Gain can show differences in the increase in the value of scientific literacy between the module class and the existing class. Normalized gain (N-Gain) does not take into account class sizes or variations in students in the classroom, but effect sizes take into account (Nugroho \& Zulfiani, 2021). Table 8 shows that the significance values greater than 0.05 (sig.> 0.05) with Ho accepted. So it can be concluded that there is no significant difference in the module and the existing class in the indicator recognizing and analyzing alternative explanations; communicating the result; understanding and analyzing data; constructing hypotheses. Although the results do not show a significant effect, Table 9 shows that the N-Gain value of the module class on each indicator is higher than the existing class.

The effectiveness rate of the heat and temperature module based on GIL can be known by the further test following MANOVA is Effect Size test. Effect size can be analyzed using partial eta-squared (Plonsky, 2018). The result of effect size based on partial eta-squared of 0,413 . The effect indicates that there is a medium impact of applying heat and temperature module to the indicator of scientific inquiry literacy. The result of this research is relevant to the research undertaken by (Aulia et al., 2018; Kusnadi et al., 2017) stating that the learning model can improve students' scientific inquiry literacy.

From Table 9, it can be found the improvement occurs in each indicator with the high category are drawing appropriate conclusions from evidence, understanding and analyzing data, designing experimental procedures, and identifying problems to be investigated.
Identifying problems to be investigated indicator allowed students to observe a phenomenon and formulate the problems contained in the module. Kusnadi et al (2018) suggested GIL learning helps students to formulate problems, find answers and solve problems to satisfy their curiosity and increase motivation to learn the principles and concepts of science. The students identified the problems obtained then analyzed them in the form of some questions which further lead to the main question. The students are allowed to be able to explain scientific phenomena such as how to make good formula milk with a certain temperature, what ingredients are suitable for maintaining coffee heat, and why do you wear a jacket and others that observed by students. The scientific questions will lead to a process for understanding a problem-based concept and making it into a hypothesis.

When students in the module class can identify and control variables, students naturally have an idea of how to design experiments by the specified variables. Students will design experiments with one variable that is changed while other variables are made constant. In the process of designing experiments, students use several scientific skills such as; collecting data, identifying variables, formulating hypotheses, and others (Ratnasari et al., 2018). Meanwhile, the skills of designing experiments are important because a lot of skills are needed for deeper analysis when conducting experiments repeatedly.

The indicator understanding and analyzing data referred how to student write their finding through experiments. The students with good analysis can explore their knowledge both through laboratory activities and literature studies. The students can undertake several learning activities such as exploring literature and laboratory activities that help them use their initial knowledge to generate new ideas.

Drawing appropriate conclusions from the evidence were carried out by discussing 
the information obtained and analyzed data. The students by gradually and systematically been able to construct their knowledge and help students to develop to think independently and structured. The students explained their findings of information and data that aim to answer the questions or problems presented in the class.

The GIL-based heat and temperature module accommodate the empowerment of scientific literacy, in this case, scientific inquiry literacy. The syntax in the module based on Guided-Inquiry Laboratory contains a series of scientific investigations that facilitate students to learn independently to empower scientific literacy. Using inquiry-based modules can help the students to determine the steps of science investigation individually so that they can develop inquiry skills (Hairida, 2016). Scientific understanding is the process by which logical principles are applied to conduct investigations such as making explanations, formulating hypotheses, making predictions, providing problem solutions, designing experimental procedures, conducting scientific investigations, analyzing and interpreting data, controlling variables, and developing theoretical laws based on scientific evidence (Opitz et al., 2017).

Many researchers have conducted other studies to empower scientific literacy (Aulia et al., 2018; Kusnadi et al., 2017; Saefullah et al., 2017; Setiawan et al., 2017; Twiningsih, 2019). The module that has been developed is used to perfect existing modules by adding missing scientific inquiry literacy components. Student activities in each GIL syntax focus on the process of stimulating scientific inquiry literacy skills that students are trained independently to design, develop and carry out experiments and collect results data. In scientific inquiry activities, students can design their experiments instead of following the verification process (Sri et al., 2019; Ural, 2016). Practical learning in the laboratory is a potential learning experience for developing high order learning skills such as observation, planning observation, formulating relevant research questions, formulating hypotheses, and analyzing experimental or experimental data (Bruckermann et al., 2017).

The laboratory activities can help students to construct their knowledge and make learning activity becomes meaningful. This is in line with the opinion of Piaget that knowledge is the result of the human thinking process that is constructed from the experience continuously and whenever possible reconstruction because of the new understanding gained through the adaptation learning process. Meaningful learning activity makes the students to actively participate. The GIL-based module being able to make students actively involved in the learning process.

The way to follow up on the results of this study is that inquiry-based learning must be taught explicitly in class. So that the learning climate will grow later that will make students do the learning that is normally done. Note that when this research ends, inquiry-based learning also ends. Also, the most common difficulty experienced by teachers is the impatience of teachers in guiding students to interpret data and make conclusions. This tendency causes the teacher to conclude by himself and the students just follow. So it is expected that teachers will have to practice a lot more regularly to be able to ask questions to guide students.

\section{CONCLUSION}

Based on the results of the analysis and discussion of the GIL-based heat and temperature module, the module was effectively empowered the students' scientific inquiry literacy. The effectiveness of heat and temperature module based on GIL can be seen from the MANOVA test with the result of the effect size obtained sig. count of 0,000 and partial eta-squared of 0,413 with the medium category. The average score of scientific inquiry literacy 
$\mathrm{N}$-Gains score calculation in the module class was higher by 0,68 compared to the existing class of 0,47 . Thus, the GIL-based heat and temperature module can be applied in classrooms to empower the science literacy of junior high school students.

\section{AUTHOR CONTRIBUTIONS}

DK conceptualize. SJ meet the validators to do validation. SK and RS designing the module product. DK, SJ and RS revise the product. DK and RS wrote the manuscript.

\section{REFERENCES}

Akani, O. (2016). An evaluation of classroom experiences of basic science. British Journal of Education, 4(1), 6476.

Ardianto, D., \& Pursitasari, I. D. (2017). Do middle school science textbook enclose an entity of science literacy? Jhss (Journal of Humanities and Social Studies), 1(1), 24-27. https://doi.org/10.33751/jhss.v1i1.369

Arifin, L., \& Sunarti, T. (2017). Peningkatan Literasi Sains Peserta Didik melalui Model Pembelajaran Guided Inquiry pada Materi Fluida Dinamis. Jurnal Penelitian Fisika Dan Aplikasinya (JPFA), 7(2), 68-78.

Astuti, E. A., Wardani, S., \& Kadarwati, S. (2019). The effectiveness of practicumbased worksheet based on salt hydrolysis material viewed from the aspect of laboratory skills and interpersonal intelligence learners. Journal of Education and Learning (EduLearn), 13(4), 502-509. https://doi.org/10.11591/edulearn.v13i4 .12397

Aulia, E. V, Poedjiastoeti, S., \& Agustini1, R. (2018). The effectiveness of Guided-Inquiry-based learning material on students' science literacy skills the effectiveness of Guided-Inquiry-based learning material on students 'science literacy skills. IOP Conf. Series: Journal of Physics: Conf. Series 947. https://doi.org/10.1088/1742-

\section{6/947/1/012049}

Bruckermann, T., Aschermann, E., Bresges, A., \& Schlüter, K. (2017). Metacognitive and multimedia support of experiments in inquiry learning for science teacher preparation. International Journal of Science Education, $\quad 0(0), \quad 1-22$. https://doi.org/10.1080/09500693.2017. 1301691

Cohen, J. (1988). Statistical power analysis for the behavioral sciences, 2 nd ed. Erlbaum.

Dhamija, N., Kanchan, M., \& Education, M. M. C. (2014). Effectiveness of self learning modules on the achievement and retention of undergraduate students in commerce. Educationia Confab, $3(2)$.

Diana, S. (2016). Pengaruh penerapan strategi peer assisted learning (PAL) terhadap kemampuan literasi sains mahasiswa dalam perkuliahan morfologi tumbuhan. Jurnal Pengajaran MIPA, 21(1), 82-91.

Fitriani, F., \& Indriaturrahmi, I. (2020). Pengembangan e-modul sebagai Sumber Belajar Mata Pelajaran Bahasa Indonesia Kelas X MAN 1 Lombok Tengah. Jurnal Penelitian dan Pengkajian Ilmu Pendidikan: $e$ Saintika, 4(1), 16-25.

Gunawan, Harjono, A., Hermansyah, \& Herayanti, L. (2019). Guided-Inquiry model through virtual laboratory to enhance students' science procces skills on heat concept. Cakrawala Pendidikan, 38(2), 259-268. https://doi.org/10.21831/cp.v38i2.2334 5

Hairida, H. (2016). The effectiveness using inquiry based natural science module with authentic assessment to improve the critical thinking and inquiry skills of junior high school students. Jurnal Pendidikan IPA Indonesia, 5(2), 209215. https://doi.org/10.15294/jpii.v5i2.7681

Innatesari, D. K., Sajidan, S., \& Sukarmin, 
S. (2019). The profile of students' scientific inquiry literacy based on scientific inquiry literacy test (ScInqLiT). Journal of Physics: Conference Series, 1227, 012040. https://doi.org/10.1088/17426596/1227/1/012040

Iskandar, Sastradika, D., \& Defrianti, D. (2019). Optimizing inquiry-based learning activity in improving students' scientific literacy skills. Journal of Physics: Conference Series, 1233(1). https://doi.org/10.1088/17426596/1233/1/012061

Jeon, Y., \& Choi, A. (2016). Analysis of inquiry activities in high school chemistry II textbooks based on the 2009 revised science curriculum: Focus on 8 science practices. Journal of the Korean Chemical Society. https://doi.org/10.5012/jkcs.2016.60.1. 59

Kuhlthau, C. C. (2010). Guided-Inquiry: school libraries in the 21 st century. School Libraries Worldwide.

Kusnadi, K., Rustaman, N. Y., Redjeki, S., \& Aryantha, I. N. P. (2017). Enhancing scientific inquiry literacy of prospective biology teachers through inquiry lab project in microbiology. IOP Conf. Series: Journal of Physics: Conf. Series, 895(ICMScE). https://doi.org/10.1088/17426596/895/1/012136

Lederman, N. G., Antink, A., \& Bartos, S. (2014). Nature of science, scientific inquiry, and socio-scientific issues arising from genetics: A pathway to developing a scientifically literate citizenry. Sci \& Educ, (23), 285-302. https://doi.org/10.1007/s11191-0129503-3

Mcdonald, C. V. (2015). Evaluating junior secondary science textbook usage in australian schools. Res Sci Educ. https://doi.org/10.1007/s11165-0159468-8

Mulhayatiah, D., Setya, W., \& Suhendi, H. Y. (2019). The impact of digital learning module in improving students' problem-solving skills. Jurnal Ilmiah Pendidikan Fisika Al-BiRuNi, 08(April), 11-22. https://doi.org/10.24042/jipfalbiruni.v8 i1.3150

Murphy, C., Smith, G., \& Broderick, N. (2019). A starting point: Provide children opportunities to engage with scientific inquiry and nature of science. Research in Science Education. https://doi.org/https://doi.org/10.1007/s 11165-019-9825-0 A

NGSS. (2013). Next generation science standards: for states, by states (Volume 1:).

Nugroho, B., \& Zulfiani, Z. (2021). A Causal-Comparative Study of InquiryBased Science Learning Based on Levels of Students' Cognitive Learning Outcomes: Systematic Review. Jurnal Pendidikan Sains Indonesia, 9(4), 651666.

Odegaard, M., Haug, B., Mork, S., \& Ove, G. (2015). Budding science and literacy . a classroom video study of the challenges and support in an integrated inquiry and literacy teaching model. Procedia-Social and Behavioral Sciences, 167(1877), 274-278. https://doi.org/10.1016/j.sbspro.2014.1 2.674

Opitz, A., Heene, M., \& Fischer, F. (2017). Measuring scientific reasoning-a review of test instruments. Educational Research and Evaluation, 23(3-4), 78101. https://doi.org/10.1080/13803611.2017. 1338586

Plonsky, L. (2018). Eta- and partial etasquared in L2 research: A cautionary review and guide to more appropriate usage Reza Norouzian. Second Language Reseacrh, 34(2), 257-271. https://doi.org/10.1177/0267658316684 904

Prihmardoyo, W., Sajidan, S., \& Maridi. (2017). Effectiveness of GuidedInquiry laboratory-based module and 
indicator of analytical thinking skills in the matter of respiratory system in senior high school. Advances in Social Science, Education and Humanities Research (ASSEHR), Volume 158 International Conference on Teacher Training and Education 2017 (ICTTE 2017), 158(ICTTE), 803-813.

Ratnasari, D., Sukarmin, S., Suparmi, S., \& Harjunowibowo, D. (2018). Analysis of science process skills of summative test items in physics of grade $X$ in Surakarta. Jurnal Pendidikan IPA Indonesia, $\quad 7(1), \quad 41-47$. https://doi.org/10.15294/jpii.v7i1.1043 9

Ristanto, R. H., Zubaidah, S., Malang, U. N., Amin, M., \& Rohman, F. (2017). Scientific literacy of students learned through Guided-Inquiry. International Journal of Research \& Review, 4(5), 23-30.

Ronnebeck, S. (2016). Searching for a common ground - a literature review of empirical reseach on scientific inquiry activities. Studies in Science Education, 52(2), 161-197. https://doi.org/10.1080/03057267.2016. 1206351

Saefullah, A., Samanhudi, U., Nulhakim, L., Berlian, L., Rakhmawan, A., Rohimah, B., ... Kingdom, U. (2017). Efforts to improve scientific literacy of students through Guided-Inquiry learning based on local wisdom o f baduy " $\mathrm{s}$ society. Jurnal Penelitian dan Pembelajaran IPA, 3(2), 84-91.

Serrat, M. A., Dom, A. M., Jr, J. T. B., Williams, A. R., Efaw, M. L., Richardson, L. L., ... Virginia, W. (2014). Performance and understanding of anatomy. Anat Sci Educ, 416(October), 406-416. https://doi.org/10.1002/ase.1438
Setiawan, B., Innatesari, D. K., Sabtiawan, W. B., \& Sudarmin, S. (2017). The development of local wisdom-based natural science module to improve science literation of students. Jurnal Pendidikan IPA Indonesia, 6(1), 4954. https://doi.org/10.15294/jpii.v6i1.9595

Sri, B., Sari, K., Jufri, A. W., Santoso, D., Studi, P., Pendidikan, M., \& Mataram, P. U. (2019). Jurnal penelitian pendidikan IPA pengembangan bahan ajar IPA berbasis inkuiri terbimbing untuk meningkatkan literasi sains. Jurnal Penelitian Pendidikan IPA, $5(2)$, 219-227. https://doi.org/10.29303/jppipa.v5i2.27 9

Twiningsih, A. (2019). The effectiveness of problem-based thematic learning module to improve primary school student's critical thinking skills. JPBI (Jurnal Pendidikan Biologi Indonesia), 5(1), 117-126.

Ural, E. (2016). The effect of guided-inquiry laboratory experiments on science education students' chemistry laboratory attitudes, anxiety and achievement. Journal Education and Training Studies, 4(4), 217-227. https://doi.org/10.11114/jets.v4i4.1395

Wang, J., Guo, D., \& Jou, M. (2015). A study on the effects of model-based inquiry pedagogy on students' inquiry skills in a virtual physics lab. Computer in Human Behavior. https://doi.org/10.1016/j.chb.2015.01.0 43

Wenning, C. J. (2011). Experimental inquiry in introductory physics courses. Journal Physics Teacher Education, 6(2), 2-8. 